\title{
Comparison of Efficacy of Amlodipine and Cilnidipine on Left Ventricular Hypertrophy amongst Hypertensive Patients
}

\section{Sougata Sarkar, Vartika Srivastava* and Manjushree Mohanty}

Department of Pharmacology, Kalinga Institute of Medical Sciences, Bhubaneswar, Odisha, India

\begin{abstract}
Left ventricular hypertrophy is one of the commonest cardiac sign seen in hypertensive patients. According to American Heart Association and Joint National Committee VIII calcium channel blockers are first line drug in treatment of hypertension. Previous meta-analysis shows Calcium channel blocker can reduce left ventricular hypertrophy by $9-11 \%$. The study was undertaken to evaluate and compare the efficacy of Amlodipine and Cilnidipine on Left ventricular hypertrophy and Systolic function. Total 48 patients were selected and enrolled as study participants. The patients were then divided as (1) Hypertensive group $(n=22)$ and (2) Diabetic hypertensive group $(n=26)$ - selected patients received either Amlodipine (2.5 to $10 \mathrm{mg}$ ) or cilnidipine (5 to $20 \mathrm{mg}$ ) with or without Angiotensin receptor blockade along with antidiabetic medication. Echocardiography report done to all selected patients at baseline and 12 months. Amlodipine and Cilnidipine, both can reduce left ventricular mass, left ventricular mass index, and relative wall thickness with statistical significance but without any clinical relevance when compared with the baseline. The total mean reduction in percentage of above parameters was more with Cilnidipine treated arm than Amlodipine. Both drugs have no effect on cardiac systolic function i.e., ejection fraction and endocardial fractional shortening. From this study it can be concluded that Cilnidipine is better in reducing left ventricular hypertrophy than Amlodipine in hypertensive patients without any deleterious action on systolic function.
\end{abstract}

Keywords: Hypertension; Amlodipine; Cilnidipine; Left ventricular hypertrophy; Left ventricular mass; Systolic dysfunction

\section{Abbreviations}

ACR: Albumin Creatinine Ratio;

AHA: American Heart Association;

CCB: Calcium Channel Blockers;

CI: Confidence Interval;

DM(-): Non Diabetic;

$\mathrm{DM}(+)$ : Diabetic;

EF: Ejection Fraction;

EFS: Endocardial Fractional Shortening;

HOCM: Hypertrophic Obstructive Cardio Myopathy;

LVH: Left Ventricular Hypertrophy;

LVM: Left Ventricular Mass;

LVMI: Left Ventricular Mass Index;

NS: Statistically non-Significant;

RAAS: Renin Angiotensin Aldosterone System;

RWT: Relative Wall Thickness;

S: Statistically Significant;

SD: Standard Deviation;

SNS: Sympathetic Nervous System;

W/C: Waist Circumference

\section{Introduction}

It is now acknowledged that, apart from mechanical stress of pressure overload, various neurohormonal substances independently exert trophic effects on myocytes and non myocytes in the heart and cause left venticular hypertrophy [1]. As shown in Table 1, trophic factors include angiotensin II, aldosterone, norepinephrine, and insulin which directly promote myocyte hypertrophy and matrix deposition independent of their effects on systemic arterial pressure [2,3]. A series of cytokines and growth factors including transforming growth factor beta, fibroblast growth factor, and insulin growth factor that are produced and stimulated by above mentioned trophins, causes stimulation of cardiac protein synthesis and hypertrophy. While elevated systemic arterial pressure is important in pathogenesis of left ventricular hypertrophy, a genetic basis must have a role as the extent of cardiac growth and response to increased pressure loading is not always uniformly associated among hypertensive patients [4]. Thus, hypertensive patients of mild to moderate extent may also present with severe hypertrophy. In addition, concentric or an eccentric type of left ventricular remodelling is independent of the extent of hypertension.

In experimental animals, the correlation between severity of cardiac hypertrophy and severity of peripheral vascular resistance was seen [5]. In another study, it was seen that echocardiographically determined LV mass correlated significantly with vascular resistance in the calf [6]. The relationships between systemic hemodynamic and the pattern of LV anatomy as well as significant positive correlation was observed between total peripheral resistance and end-diastolic LV relative wall

*Corresponding author: Dr Vartika Srivastava, MBBS, MD, Department of Pharmacology, Kalinga Institute of Medical Sciences, Campus 5, Patia, Bhubaneswar, Odisha 751024, India, Tel: +919661809975; E-mail: mscutesmile.1886@gmail.com

Received September 18, 2017; Accepted September 25, 2017; Published September 29, 2017

Citation: Sarkar S, Srivastava V, Mohanty M (2017) Comparison of Efficacy of Amlodipine and Cilnidipine on Left Ventricular Hypertrophy amongst Hypertensive Patients. J Hypertens (Los Angel) 6: 244. doi: 10.4172/2167-1095.1000244

Copyright: ( 2017 Sarkar S, et al. This is an open-access article distributed under the terms of the Creative Commons Attribution License, which permits unrestricted use, distribution, and reproduction in any medium, provided the original author and source are credited. 
Citation: Sarkar S, Srivastava V, Mohanty M (2017) Comparison of Efficacy of Amlodipine and Cilnidipine on Left Ventricular Hypertrophy amongst Hypertensive Patients. J Hypertens (Los Angel) 6: 244. doi: 10.4172/2167-1095.1000244

Page 2 of 8

thickness (RWT) in essential hypertensive patients is well established [7].

The recent reliable evidence for an association between increased cardiac sympathetic activity and hypertensive LV hypertrophy in humans [8]. Angiotensin II and aldosterone were demonstrated to play an important role in the development of ventricular remodelling in animal model [9]. Catecholamine hypothesis of LVH was inferred from studies using sympathetic agonists [10] and antagonists [11] in intact animals. It was also seen that, in tissue-cultured of cardiac myocytes in presence of norepinephrine, alfa receptor is responsible for protein synthesis [12]. Some studies in essential hypertensive patient had shown a positive relationship between plasma norepinephrine concentration and LV mass as well as a greater reduction in LV mass was seen than blood pressure reduction during treatment with sympatholytic drugs [13-15]. But these results have not been consistently observed [16]. However, study on pheochromocytoma patient suggests that reliability of the catecholamine hypothesis to clinical hypertension may be limited [17].

Various experiments have shown that renin-angiotensin system activity is responsible for myocardial hypertrophy. It was also reported that radiolabeled angiotensin II is rapidly localized in nuclei of cardiac and smooth muscle cells [18], and a significant increase in ventricular weight after 6 days of angiotensin II infusion at a mildly pressor dose was also documented [19]. Some studies of patients treated with angiotensin converting enzyme inhibitors have suggested that echocardiographic LV mass may decrease more than expected for the induced reduction in blood pressure, [20] but this finding has not been consistent [20-22].

According to JNC VIII and AHA guidelines calcium channel blockers are first line of treatment in treatment of hypertension both general black and non-black population (including those with diabetes) [23]. Treatment of hypertension is carried out by long acting CCB, on the basis of different sub types of calcium channels they block. All the $3^{\text {rd }}$ generation calcium channels acts significantly only on voltage gated L-type calcium channels, expressed on vascular smooth muscle [24]. A unique $4^{\text {th }}$ generation 1, 4 dihydropyridine derivative calcium channel blocker Cilnidipine, that inhibits multiple calcium channels have been developed over the past decade. Cilnidipine acts significantly both on $\mathrm{N}$-type calcium channels located on peripheral sympathetic nerve fibres and L-type calcium channels located on vasculature is approved for therapy of essential hypertension [25].

The strong antihypertensive effect of CCB has been reported to cause reflex activation of the SNS and RAAS [26]. Furthermore, excess calcium levels have been reported to inhibit renin expression in juxtaglomerular cells by the direct inhibition of gene transcription and destabilization of renin mRNA [27]. L-type CCB might therefore increase renin transcription in the juxtaglomerular cells. However, the blockade of $\mathrm{T}$ - and N-type calcium channels did not affect calcium influx in these cells [28]. Cilnidipine, an L/N type CCB, has been reported to suppress the SNS over-activation associated with RAAS activation by blocking $\mathrm{N}$-type calcium channels and to inhibit renin transcription in juxtaglomerular cells [29-32]. So Cilnidipine could attenuate the SNS and RAAS activation induced by its own blockade of L-type calcium channels.

\section{Aims and objective}

With this background knowledge present study was undertaken to throw some light into the effect of two different CCBs on cardiovascular parameters: (i) Comparative assessment of Amlodipine or Cilnidipine, in reducing left ventricular hypertrophy.

(ii) Comparison of effect of Amlodipine and Cilnidipine on systolic function.

(iii) To compare the above mentioned parameters in diabetic and non-diabetic hypertensive patients.

\section{Materials and Methods}

\section{Overview of the experiment}

This was a comparative, non-blinded, single centred, prospective and parallel groups, observational study was conducted in medicine OPD clinic of KIMS over a period of 24 months. The study was approved by the Institutional Ethical Committee, KIMS, BBSR. Written informed consent of all patients participating in the study was obtained. Hypertensive patients on the basis of inclusion and exclusion criteria were selected for the study.

\section{Selection of study population:}

\section{Inclusion criteria:}

Age: $\geq 40$ yrs $\leq 60$ yrs.

BMI $\geq 18.5 \leq 29.99 \mathrm{~kg} \mathrm{~m}^{-2}$ (normal and pre-obese). Sex: Both sex.

New essential hypertensive patients with stage 1 and stage 2 hypertension according to the JNC 7 (those $\mathrm{SBP}<180$ and $\mathrm{DBP}<110$ ) - who were initiated with Amlodipine (2.5 to $10 \mathrm{mg}$ ) or Cilnidipine (5 to $20 \mathrm{mg}$ ) treatment.

Uncontrolled hypertensive (essential) patients on ARB/ACEI who were started with Amlodipine (2.5 to $10 \mathrm{mg}$ ) or Cilnidipine (5 to $20 \mathrm{mg}$ ) treatment as add on therapy. Controlled diabetic patient (HBA1c $\leq 7)$.

\section{Exclusion criteria:}

Age : $<40$ yrs $>60$ yrs.

BMI : $<18.5$ to $>29.99 \mathrm{~kg} \mathrm{~m}^{-2}$.

All cases of hypertension with SBP $\geq 180$ and DBP $\geq 110$.

Patients of secondary hypertension or taking antihypertensive medicine other than additional ACEI / ARB.

Uncontrolled diabetes (HBAlc >7).

Patient with liver, kidney and thyroid disease.

Patients with heart failure, CAD, heart block and aortic stenosis. On NSAID for long term; corticosteroid and sex steroids. Any other chronic illness (RA, TB, PEM). Alcoholic (consume more than moderate amount), smoker.

\section{Patient recruitment and grouping}

Patients with hypertension meeting the above criteria, reporting in the department of medicine between September 14 to August 16 for their treatment, were enrolled in study. Total 62 patients were screened and examined, amongst them 57 patients were selected and enrolled as study participants during that period. The study was explained to them in local language and written informed consent was obtained. The enrolled patients were then divided as (1) Hypertensive group- selected patients received either Amlodipine (2.5 to $10 \mathrm{mg}$ ) or cilnidipine (5 to $20 \mathrm{mg}$ ). (2) Diabetic hypertensive group - are also grouped accordingly (The grouping is depicted by flowchart below). Patients were instructed 
to attend the hypertension clinic immediately in case of any adverse event, along with advised for salt restriction (no added salt) and regular physical exercise. Diabetic hypertensive patients were also advised for strict diabetic diet as prescribed by dietician and to continue their antidiabetic medication and regular follow up at OPD for control of diabetes. All patients were also advised to stop addiction if any. Adherence was monitored by pill count. All patients were examined periodically at intervals 14 days, $1 \mathrm{~m}, 3 \mathrm{~m}, 6 \mathrm{~m}$, and $12 \mathrm{~m}$. Dose of amlodipine and cilnidipine were titrated and additional antihypertensive (ARB/ACEI) were added by physician according to their BP goal during first month. We exclude the data of drop out participants (total no of dropout 9), patients withdrawing consent, intolerable to medication, doctor's discretion, loss of follow-up and any protocol violation like those patients for whom additional anti-hypertensive were added other than ARB or ACEI for inadequate BP control. Ultimately the study was continued with total 48 patients amongst them, 22 were hypertensive (on Amlodipine $\mathrm{n}=12$, on Cilnidipine $\mathrm{n}=10$ ) and 26 were diabetic hypertensive patients (on Amlodipine $\mathrm{n}=12$, on Cilnidipine $\mathrm{n}=14$ ). The grouping is depicted by flowchart below (Figure 1).

\section{Echocardiography (2D and $M$ mode)}

Echocardiography (2D and $\mathrm{M}$ mode) was done to all patients at initiation and at the end of the study. That excluded any valvular heart disease, cardiomyopathy, wall hypokinesia, HOCM, ishemic heart disease, heart failure i.e., those patients having heart disease at base line. We measured left ventricular mass (LVM), left ventricular mass index (LVMI), relative wall thickness (RWT), endocardial fractional shortening (EFS) by online computer based calculator provided by Canadian Society OfEchocardiography (http://csecho.ca/mdmath/?tag=lvmlvmi) from the parameters given in the echocardiography report i.e., LVEDD (left ventricular end-diastolic diameter), LVESD (left ventricular endsystolic diameter), PWTd (diastolic posterior wall thickness), SWTd (diastolic septal wall thickness). We got the Ejection Fraction report from the echocardiography report itself.

\section{Analysis of data by applying statistics}

The collected data of the above mentioned parameters was compiled, tabulated and entered in Microsoft Excel 2013 (15.0.4551.1011) and statistically analysed by using Graph Pad Prism 7 (http://graphpad. com/quickcalcs/ttest1/?Format=C) for determination of significance. The result of this analysis was used to provide the final comparison of data to finalize the study results. 'p' value was determined to finally evaluate the levels of significance based on the data related to drug efficacy using paired and unpaired T-test and Fisher's test. 'p' value of $<0.05$ was considered significant. The clinical relevance of the results in the light of statistical analysis was displayed (at 95\% CI) and discussed. Also, the comparison of the cost as per the efficacy was carried out in MS Excel Spreadsheet 2013.

\section{Determination of predetermined clinical relevant margin}

Minimal clinical important difference (MICD) or clinically meaningful difference (CMD) was determined taking into account of previous meta-analysis $[33,34]$ on LVH reduction by antihypertensive and potential source of variability in 2D [35] / M-mode [36-42] measurement. In the present study, change in $17 \mathrm{gm}$ for LVM, $10 \mathrm{gm}$ $\mathrm{m}^{-2}$ for LVMI and 0.04 for RWT (i.e., $10 \%$ variation of LVM, LVMI and RWT from baseline of total study population was taken as MICD.

\section{Results}

Table 2 shows both groups i.e., hypertensive and diabetic

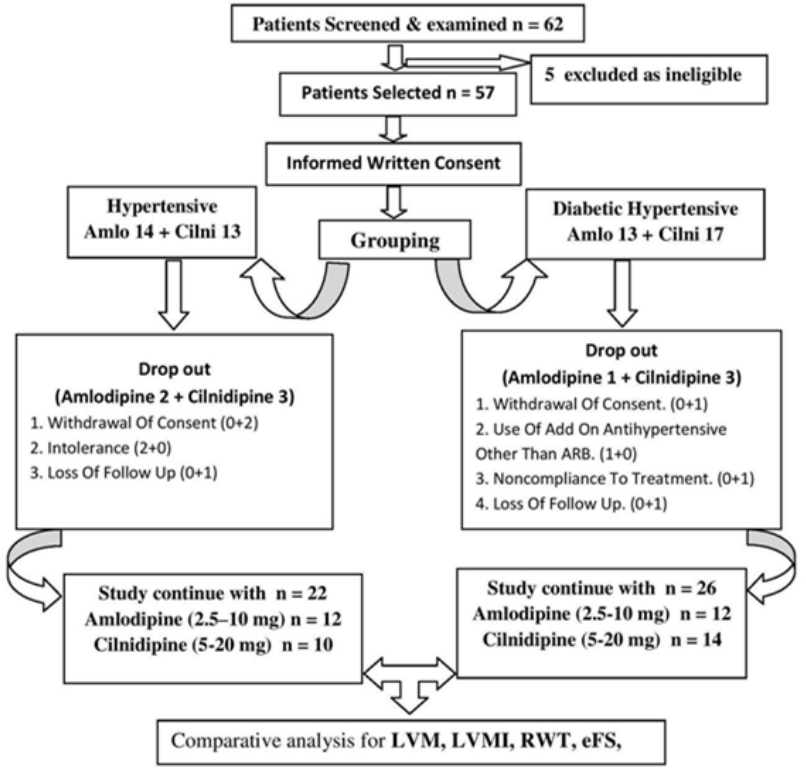

Figure 1: Flowchart depicts the grouping procedure.

\begin{tabular}{|c|}
\hline Hypertension \\
\hline Neurohormonal factors (growth stimulation) \\
\hline Angiotensin II \\
\hline Aldosterone \\
\hline Norepinephrine \\
\hline Insulin and other growth factors \\
\hline Genetic Influences. \\
\hline
\end{tabular}

Table 1: Factors promoting left ventricular hypertrophy.

hypertensive patients, are identical including medication, as statistical analysis of all baseline data were appeared to be non-significant.

Table 3 shows statistically highly significant $(\mathrm{p}<0.001)$ reduction in LVM, LVMI and RWT were seen with Amlodipine and Cilnidipine (without any clinical relevance) treatment in both hypertensive and diabetic hypertensive patients when compared with the base line.

Table 4 shows the reduction in LVM, LVMI and RWT when compared between Amlodipine and Cilnidipine amongst hypertensive and diabetic hypertensive patients, was observed to be statistically significant (except RWT in diabetic).

\section{Discussion}

Table 2 shows the comparison of demographic (Age, sex, BMI, waist circumference, weight, height), baseline parameters, prescribing pattern of antihypertensive drug and dose (Amlodipine or Cilnidipine with or without additional ARB) between Amlodipine and Cilnidipine group in hypertensive and diabetic hypertensive patients. There was no significant difference noted between these two groups at the initiation of the study. Table 3 also shows that at initiation all echocardiography parameters like LVM, LVMI, RWT, eFS, EF were comparable in both group.

Present study shows that (Table 3) there was statistically significant reduction in Left Ventricular Mass (LVM) from base line with 12 
Citation: Sarkar S, Srivastava V, Mohanty M (2017) Comparison of Efficacy of Amlodipine and Cilnidipine on Left Ventricular Hypertrophy amongst Hypertensive Patients. J Hypertens (Los Angel) 6: 244. doi: 10.4172/2167-1095.1000244

Page 4 of 8

\begin{tabular}{|c|c|c|c|c|c|c|}
\hline \multirow{2}{*}{$\begin{array}{l}\text { Data Analysed } \\
\text { ( Mean } \pm \text { SD) }\end{array}$} & \multicolumn{3}{|c|}{$\begin{array}{l}\text { Hypertensive Patients } \\
\qquad \mathrm{N}=\mathbf{2 2}\end{array}$} & \multicolumn{3}{|c|}{$\begin{array}{l}\text { Diabetic Hypertensive Patients } \\
\qquad N=26\end{array}$} \\
\hline & $\begin{array}{l}\text { Amlodipine } \\
\qquad \mathrm{N}=12\end{array}$ & $\begin{array}{l}\text { Cilnidipine } \\
\qquad \mathrm{N}=10\end{array}$ & $\begin{array}{c}\text { P } \\
\text { Value }\end{array}$ & $\begin{array}{l}\text { Amlodipine } \\
\qquad \mathrm{N}=12\end{array}$ & $\begin{array}{l}\text { Cilnidipine } \\
\qquad \mathrm{N}=14\end{array}$ & $\begin{array}{c}\mathrm{P} \\
\text { Value }\end{array}$ \\
\hline Sex F/M & $6 / 6$ & $4 / 6$ & $\begin{array}{c}0.6914 \\
\mathrm{NS}^{*}\end{array}$ & $4 / 8$ & $5 / 9$ & $\begin{array}{l}1.0000 \\
N^{*}\end{array}$ \\
\hline Age & $56.83 \pm 2.04$ & $\begin{array}{c}57.10 \pm \\
2.81\end{array}$ & $\begin{array}{c}0.7991 \\
\text { NS }\end{array}$ & $\begin{array}{c}56.92 \pm \\
2.81\end{array}$ & $56 \pm 3.33$ & $\begin{array}{c}0.4598 \\
\text { NS }\end{array}$ \\
\hline BMI & $21.58 \pm 2.72$ & $\begin{array}{c}22.82 \pm \\
3.03\end{array}$ & $\begin{array}{c}0.3224 \\
\text { NS }\end{array}$ & $\begin{array}{c}23.09 \pm \\
3.57\end{array}$ & $23.05 \pm 1.19$ & $\begin{array}{c}0.9692 \\
\text { NS }\end{array}$ \\
\hline W/C & $30.24 \pm 5.12$ & $31.25 \pm 5.1$ & $\begin{array}{c}0.6498 \\
\text { NS }\end{array}$ & $31.98 \pm 4.4$ & $31.72 \pm 3.56$ & $\begin{array}{c}0.8717 \\
\text { NS }\end{array}$ \\
\hline Weight & $\begin{array}{c}58.24 \pm \\
10.41\end{array}$ & $\begin{array}{c}64.23 \pm \\
17.13\end{array}$ & $\begin{array}{c}0.3244 \\
\text { NS }\end{array}$ & $\begin{array}{c}65.88 \pm \\
15.29\end{array}$ & $64.87 \pm 12.7$ & $\begin{array}{c}0.8552 \\
\text { NS }\end{array}$ \\
\hline Height & $5.28 \pm 0.33$ & $\begin{array}{c}5.45 \pm \\
0.44\end{array}$ & $\begin{array}{c}0.3008 \\
\text { NS }\end{array}$ & $5.51 \pm 0.28$ & $5.49 \pm 0.41$ & $\begin{array}{c}0.8813 \\
\text { NS }\end{array}$ \\
\hline SBP & $\begin{array}{c}160.17 \pm \\
7.91\end{array}$ & $\begin{array}{c}162.90 \pm \\
8.33\end{array}$ & $\begin{array}{c}0.4399 \\
\text { NS }\end{array}$ & $\begin{array}{c}157.17 \pm \\
9.88\end{array}$ & $\begin{array}{c}157.5 \pm \\
10.28\end{array}$ & $\begin{array}{c}0.9388 \\
\text { NS }\end{array}$ \\
\hline DBP & $94.83 \pm 5.77$ & $\begin{array}{c}94.30 \pm \\
7.48\end{array}$ & $\begin{array}{c}0.8521 \\
\text { NS }\end{array}$ & $93.67 \pm 4.6$ & $95.79 \pm 4.21$ & $\begin{array}{c}0.2320 \\
\text { NS }\end{array}$ \\
\hline $\begin{array}{c}\text { On additional } \\
\text { ARBs }\end{array}$ & 4 & 5 & $\begin{array}{c}0.7184 \\
\text { NS }\end{array}$ & 5 & 5 & $\begin{array}{c}0.9203 \\
\text { NS }\end{array}$ \\
\hline $\begin{array}{l}\text { Amlo } 2.5 \mathrm{mg} / \\
\text { Cilni } 5 \mathrm{mg}\end{array}$ & 3 & 2 & 0.9608 & 4 & 6 & 0.7189 \\
\hline $\begin{array}{l}\text { Amlo } 5 \text { mg/ } \\
\text { Cilni } 10 \text { mg }\end{array}$ & 9 & 8 & NS & 7 & 6 & NS \\
\hline $\begin{array}{l}\text { Amlo } 10 \mathrm{mg} / \\
\text { Cilni } 20 \mathrm{mg}\end{array}$ & 0 & 0 & & 1 & 2 & \\
\hline
\end{tabular}

*Note: SD - Standard deviation; BMI - Body mass index ; W/C - Waist circumferance ; SBP - Systolic blood pressure; DBP-Diastolic blood. NS- Non significant. Statics applied: Unpaired t test and Fisher's exact test $\left({ }^{*}\right)$, Amlo - Amlodipine, Cilni - Cilnidipine, ARB - Angiotensin receptor blocker. ${ }^{*}$ The table shows both group are identical including medication, as statistical analysis of all baseline data were appeared to be non-significant

Table 2: Showing the baseline, demographic parameters and medication used, of hypertensive patients including both hypertensive and diabetic hypertensive groups who had undergone echocardiography.

\begin{tabular}{|c|c|c|c|c|c|c|c|}
\hline \multirow{2}{*}{\multicolumn{2}{|c|}{$\begin{array}{c}\text { Data Analysed } \\
\text { ( Mean } \pm \text { SD) }\end{array}$}} & \multicolumn{3}{|c|}{$\begin{array}{l}\text { Hypertensive Patients } \\
\qquad n=22\end{array}$} & \multicolumn{3}{|c|}{ Diabetic Hypertensive Patients } \\
\hline & & $\begin{array}{l}\text { Amlodipine } \\
\qquad \mathrm{N}=12\end{array}$ & $\begin{array}{l}\text { Cilnidipine } \\
\qquad N=10\end{array}$ & P Value & $\begin{array}{l}\text { Amlodipine } \\
\qquad \mathrm{N}=12\end{array}$ & $\begin{array}{l}\text { Cilnidipine } \\
\qquad N=14\end{array}$ & P Value \\
\hline \multirow[b]{2}{*}{ LVM } & $\begin{array}{l}\text { Base } \\
\text { Line }\end{array}$ & $\begin{array}{c}174.5 \pm \\
42.5\end{array}$ & $\begin{array}{c}192.8 \pm \\
42.45\end{array}$ & $\begin{array}{c}0.3263 \\
\text { NS }\end{array}$ & $\begin{array}{c}148.33 \pm \\
48.14\end{array}$ & $\begin{array}{c}177.5 \pm \\
63.27\end{array}$ & $\begin{array}{c}0.2045 \\
\text { NS }\end{array}$ \\
\hline & $\begin{array}{c}12 \text { * } \\
\text { Months }\end{array}$ & $168 \pm 41.06$ & $\begin{array}{c}181.3 \pm \\
41.18\end{array}$ & $\begin{array}{c}0.4587 \\
\text { NS }\end{array}$ & $\begin{array}{c}143.92 \pm \\
44.79\end{array}$ & $\begin{array}{c}165.43 \pm \\
53.94\end{array}$ & $\begin{array}{c}0.2845 \\
\text { NS }\end{array}$ \\
\hline
\end{tabular}


Citation: Sarkar S, Srivastava V, Mohanty M (2017) Comparison of Efficacy of Amlodipine and Cilnidipine on Left Ventricular Hypertrophy amongst Hypertensive Patients. J Hypertens (Los Angel) 6: 244. doi: 10.4172/2167-1095.1000244

Page 5 of 8

\begin{tabular}{|c|c|c|c|c|c|c|c|}
\hline & P Value & $<0.0001$ & $<0.0001$ & - & 0.0045 & 0.0005 & - \\
\hline \multirow{5}{*}{ LVMI } & Base & $107.42 \pm$ & $115+2387$ & 0.4761 & $85.67 \pm$ & $104.14 \pm$ & 0.2033 \\
\hline & Line & 24.80 & & NS & 27.73 & 41.59 & NS \\
\hline & & & $107.2 \pm 22$ & & & & 0.2718 \\
\hline & Months & 24.18 & & NS & 25.85 & 35.24 & NS \\
\hline & P Value & $<0.0001$ & 0.0006 & - & 0.0036 & 0.0012 & - \\
\hline \multirow{5}{*}{ RWT } & Base & $0.402 \pm$ & $0.44 \pm$ & 0.2658 & $0.39 \pm 0.07$ & $0.40 \pm$ & 0.8255 \\
\hline & Line & 0.09 & 0.058 & NS & & 0.07 & NS \\
\hline & 12 * & $0.39 \pm 0.08$ & $0.42 \pm 0.05$ & 0.3921 & $0.382 \pm$ & $0.381 \pm$ & 0.9594 \\
\hline & Months & & & NS & 0.06 & 0.06 & NS \\
\hline & P Value & 0.0003 & $<0.0001$ & - & 0.0009 & 0.0003 & - \\
\hline \multirow{5}{*}{ eFS } & Base & $35.489 \pm$ & $34.54 \pm$ & 0.6357 & $34.54 \pm$ & $34.52 \pm$ & 0.9897 \\
\hline & Line & 4.51 & 4.71 & NS & 4.43 & 6.11 & NS \\
\hline & 12 & $35.41 \pm$ & $34.49 \pm$ & 0.6477 & $34.80 \pm$ & $34.8 \pm$ & 0.9995 \\
\hline & Months & 4.64 & 4.66 & NS & 4.39 & 6.17 & NS \\
\hline & P Value & 0.6742 & 1.000 & - & 0.7227 & 0.3356 & - \\
\hline \multirow{5}{*}{ EF } & Base & $64.42 \pm$ & $63.40 \pm$ & 0.6371 & $63.58 \pm$ & $63.43 \pm$ & 0.9462 \\
\hline & Line & 4.81 & 5.13 & NS & 4.96 & 6.37 & NS \\
\hline & 12 & $64.5 \pm 4.81$ & $63.4 \pm 5.1$ & 0.6092 & $63.67 \pm$ & $63.57 \pm$ & 0.9673 \\
\hline & Months & & & NS & 4.89 & 6.54 & NS \\
\hline & P Value & 0.6573 & 0.7241 & - & 0.0830 & 0.0611 & - \\
\hline
\end{tabular}

*Note: SD - Standard deviation; NS - not significant; LVM - Left ventricular mass; LVMI - Left ventricular mass index; RWT - Relative wall thickness; eFS - Endocardial fractional shortening; EF - Ejection fraction; Statics applied :: Unpaired t test and paired t test. $\left({ }^{*}\right)$ : Statistically highly significant $(p<0.001)$ reduction in LVM, LVMI and RWT were seen with Amlodipine and Cilnidipine (without any clinical relevance) treatment in both hypertensive and diabetic hypertensive patients when compared with the base line

Table 3: Showing analysis of "Echocardiographic Parameters", on comparison between amlodipine and cilnidipine treatment amongst both hypertensive and diabetic hypertensive patients.

\begin{tabular}{|c|c|c|c|c|c|c|}
\hline \multirow{2}{*}{$\begin{array}{l}\text { Total mean } \\
\text { reduction } \\
\text { in (\%) } \\
\text { MEAN } \pm S D\end{array}$} & \multicolumn{3}{|c|}{$\begin{array}{l}\text { Non diabetic hypertensive patients } \\
\qquad \mathrm{N} 22\end{array}$} & \multicolumn{3}{|c|}{$\begin{array}{l}\text { Diabetic hypertensive patients } \\
\qquad \text { N } 26\end{array}$} \\
\hline & $\begin{array}{l}\text { Amlodipine } \\
\qquad \text { N } 12\end{array}$ & $\begin{array}{l}\text { Cilnidipine } \\
\text { N } 10\end{array}$ & P Value & $\begin{array}{l}\text { Amlodipine } \\
\text { N } 12\end{array}$ & $\begin{array}{l}\text { Cilnidipine } \\
\text { N } 14\end{array}$ & P Value \\
\hline LVM & $3.71 \pm 1.78$ & $6.02 \pm 2.39$ & $0.0172 \mathrm{~S}$ & $2.53 \pm 2.49$ & $5.7 \pm 3.72$ & $0.0194 \mathrm{~S}$ \\
\hline LVMI & $3.56 \pm 1.81$ & $6.67 \pm 3.53$ & $0.0147 \mathrm{~S}$ & $2.61 \pm 2.31$ & $5.65 \pm 3.88$ & $0.0263 \mathrm{~S}$ \\
\hline RWT & $3.14 \pm 1.54$ & $5.39 \pm 2.09$ & $0.0087 \mathrm{~S}$ & $2.63 \pm 1.69$ & $4.24 \pm 2.86$ & 0.099 NS \\
\hline
\end{tabular}

*Note: SD - Standard deviation; S - significant; NS - not significant; LVM - Left ventricular mass; LVMI - Left ventricular mass index; RWT - Relative wall thickness; Statics applied; Unpaired t test. $\left(^{*}\right)$ : The reduction in LVM, LVMI and RWT when compared between Amlodipine and Cilnidipine amongst hypertensive and diabetic hypertensive patients, was observed to be statistically significant (except RWT in diabetic)

Table 4: Showing comparison of total mean reduction in percentage of "Echocardiographic Parameters", between amlodipine and cilnidipine treatment amongst both hypertensive and diabetic hypertensive patients.

months of cilnidipine treatment $(\mathrm{p}<0.0001 ; 95 \%$ CI. $8.28<11.50<14.72$ in DM (-) and p=0.0005; 95\% CI, $6.35<12.07<17.79$ in DM $(+))$ as well as Amlodipine treatment $(\mathrm{p}<0.0001 ; 95 \% \mathrm{CI}, 4.21<6.50<8.79$ in DM (-); $\mathrm{p}=0.0045 ; 95 \%$ CI, $1.69<4.42<7.15$ in DM (+)) but without any clinical relevance. Similarly reduction in Left Ventricular Mass index (LVMI) from base line with 12 months of Cilnidipine treatment ( $\mathrm{p}=0.0006 ; 95 \%$ CI, $4.36<7.80<11.24$ in DM(-); $\mathrm{p}=0.0012$; 95\% CI, 3.44 $<7.21<10.99$ in $\mathrm{DM}(+))$ and Amlodipine treatment, $(\mathrm{p}<0.0001 ; 95 \%$
CI, $2.40<3.83<5.26$ in DM(-); p=0.0036; 95\% CI, $1.04<2.58<4.13$ in $\mathrm{DM}(+))$ was statistically significant but without any clinical relevance. Present study also showed that there was statistically significant reduction in Relative Wall Thickness (RWT) (Table 3) from baseline with Cilnidipine treatment $(\mathrm{p}<0.0001 ; 95 \%$ CI, $0.017<0.024<0.032$ in $\mathrm{DM}(-) ; \mathrm{p}=0.0003 ; 95 \% \mathrm{CI}, 0.010<0.018<0.026$ in $\mathrm{DM}(+))$ as well as with Amlodipine treatment ( $\mathrm{p}=0.0003 ; 95 \% \mathrm{CI}, 0.008<0.013<0.019$ in $\mathrm{DM}(-)$; $\mathrm{p}=0.0009 ; 95 \% \mathrm{CI}, 0.005<0.011<0.016$ in $\mathrm{DM}(+))$, but not 
Citation: Sarkar S, Srivastava V, Mohanty M (2017) Comparison of Efficacy of Amlodipine and Cilnidipine on Left Ventricular Hypertrophy amongst Hypertensive Patients. J Hypertens (Los Angel) 6: 244. doi: 10.4172/2167-1095.1000244

Page 6 of 8

found to have any clinical importance.

A statistically significant difference in the total mean change, in percentage (Table 4) of the LVM ( $\mathrm{p}=0.0172 \mathrm{DM}(-) ; 0.0194 \mathrm{DM}$ $(+))$, LVMI ( $\mathrm{p}=0.0147$ DM (-); $0.0263 \mathrm{DM}(+))$, was noted between Amlodipine and Cilnidipine group after 12 months of treatment in both DM (+) and DM (-) group. On the other hand total mean change in percentage of the RWT between Amlodipine and Cilnidipine group at the end of treatment is statistically significant ( $\mathrm{p}=0.0087)$ in $\mathrm{DM}(-)$ group but not in DM $(+)$ group ( $\mathrm{p}=0.0998)$. The changes in all above parameters were more with Cilnidipine treated arm than Amlodipine as seen in present study (Figure 2).

One previous study showed LVMI was significantly decreased after 6 months of Cilnidipine treatment, though there were no significant changes in LV end-diastolic and end-systolic dimensions [43]. Another study showed that in hypertensive patients with neurovascular compression of the rostral ventro-lateral medulla (increased sympathetic nerve activity), Cilnidipine reduces left ventricular mass [44], these two studies are corroborative with present study. A significant reduction in left ventricular mass index with relatively short course of Amlodipine [45], in the patients with concentric LVH, Amlodipine treatment produced significant regression in hypertrophy [46], as well as Amlodipine caused significant reduction in LV Mass and RWT coincides with present study [47].

In Dahl salt-sensitive rat model, Cilnidipine reduces relative wall thickness more than Amlodipine [48], Cilnidipine significantly improved LVMI than that of control CCBs group and Cilnidipine reduces LV mass index significantly after 3 months of the initiation of treatment whereas Amlodipine do so 6 months after the initiation of treatment, also corroborates with the result of present study $[49,50]$.

The more change may be due to additional N-type calcium channel blocking property of Cilnidipine and thereby reduction of the neurohormonal factors apart from reduction of BP i.e., peripheral vascular resistance by conventional $\mathrm{L}$ type calcium channel blocking property of all CCB. The finding can be explained by, $\mathrm{N}$-type $\mathrm{Ca} 2+$ channel blockade of Cilnidipine inhibit catecholamine release from the sympathetic nerve ending and adrenal gland [29,30], leading to suppression of the renin-angiotensin-aldosterone system [51], and suppression of aldosterone secretion from adrenocortical cells [52]. In contrast, Amlodipine might have activated the renin-angiotensinaldosterone system by increasing the sympathetic tone as well as by increase renin synthesis by JG cells $[27,53,54]$. Amlodipine decreases the mean blood pressure to a similar extent to that of Cilnidipine, established by number of previous studies. So it is obvious that Cilnidipine reduce the neurohormonal factors which are responsible for LVH whereas Amlodipine may increase those factors. Regression of LV mass was the larger in patients with the greater decrease in Plasma Aldosterone Concentration associated with antihypertensive medication regardless of CCB or ARB [55].

Present study also showed that there was no significant change (Table 3) in Endocardial Fractional Shortening (eFS) (with Amlodipine $\mathrm{p}=0.6742 \mathrm{DM}(-) ; 0.7227 \mathrm{DM}(+)$, with Cilnidipine $\mathrm{p}=1.000$ in $\mathrm{DM}(-)$ and 0.3356 in $\mathrm{DM}(+)$ ) and Ejection fraction $(\mathrm{EF})$ (with Amlodipine $\mathrm{p}$ $0.6573 \mathrm{DM}(-) ; 0.0830 \mathrm{DM}(+)$, with Cilnidipine $\mathrm{p}=0.7241$ in $\mathrm{DM}(-)$ and 0.0611 in $\mathrm{DM}(+))$ after 12 months treatment by either drug.

When \%FS was used as an index to evaluate LV systolic pump function, there were no significant changes in \%FS during treatment with Cilnidipine [43], Cilnidipine treatment has no effect on EF and eFS [56], the left ventricular ejection fraction was unaltered after

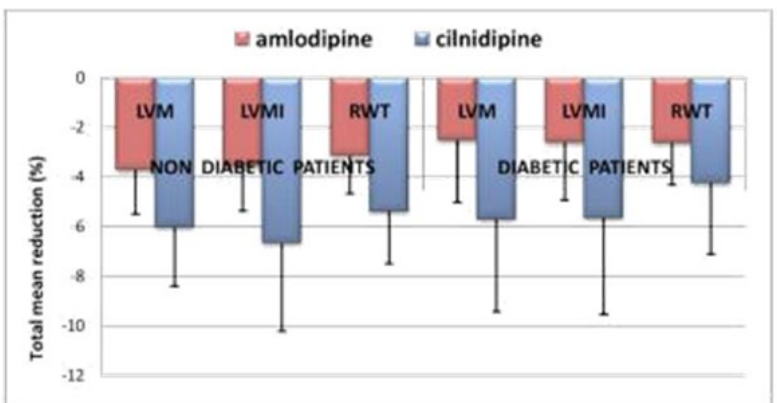

- This figure depicts reduction of LVM. LVMI and RWT was more by Cilnidipine when compared to Amlodipine treatment.

Figure 2: Bar diagram showing total mean decrease in LVM (left ventricular mass in gm), LVMI (left ventricular mass index in $\mathrm{gm} \mathrm{m}^{-2}$ ), RWT (relative wall thickness) expressed in percentage with amlodipine and cilnidipine treatment after 12 months.

Amlodipine either at rest or during exercise [57,58] and Amlodipine did not affect LVEF at rest or during exercise [59], are corroborative with present study.

There were no difference in efficacy in reducing LVH was noted by both Amlodipine and Cilnidipine amongst hypertensive and diabetic hypertensive patients.

\section{Conclusion}

Present study concluded that Cilnidipine is better in reducing LVH (LVM, LVMI, RWT) than Amlodipine in hypertensive patients without any deleterious action on systolic function (eFS, EF) and both drug have similar action in diabetic and non-diabetic patients.

\section{Novelty and Significance}

It is well established in Framingham heart study by Levy D et al. that LVM is strongly associated with the incidence of coronary heart disease and for every increase of $50 \mathrm{gm} / \mathrm{m}$ in height corrected LVM there was (after adjustment for other risk factors) approximately a 1.5 -fold increase in cardiovascular disease and death rates either sex. So antihypertensive drugs which have better hypertrophy reducing property should preferred in the hypertension management.

Long term hypertension is one of the causes of $\mathrm{LVH}$, so antihypertensive drugs reducing both hypertension and left ventricular mass simultaneously are better choice.

Present study concluded that Cilnidipine is better in reducing LVH than Amlodipine in hypertensive patients without any deleterious action on systolic function and both drug have similar action in diabetic and non-diabetic patients.

\section{References}

1. Post WS, Larson MG, Levy D (1994) Impact of left ventricular structure on the incidence of hypertension: the Framingham Heart Study. Circulation 90: $179-185$.

2. Anversa P, Puntillo E, Olivetti G, Sonnenblick E, Capasso J (1990) Cellular and mechanical adaptations in cardiac hypertrophy and its reversal. Cardiovascular reviews and reports 11: 34-42.

3. Johnson DB, Dell'Italia LJ (1996) Cardiac hypertrophy and failure in hypertension. Current Opinion in Nephrology and Hypertension 5:186-191.

4. Simpson TE, Dansky HM, Buttrick PM (1995) Molecular genetics mechanisms of cardiac hypertrophy. Cardiovascular Risk Factors 5: 93-108. 
Citation: Sarkar S, Srivastava V, Mohanty M (2017) Comparison of Efficacy of Amlodipine and Cilnidipine on Left Ventricular Hypertrophy amongst Hypertensive Patients. J Hypertens (Los Angel) 6: 244. doi: 10.4172/2167-1095.1000244

5. Folkow B (1978) Cardiovascular structural adaptation: its role in the initiation and maintenance of primary hypertension. Clin Sci 5: 3-22.

6. Shkhvatsabaya IK, Usubaliyer NN, Yurenev AP, Panfilow W (1981) The interrelation of cardiac and vascular wall hypertrophy in arterial hypertension. Cardiovasc Rev Rep 2: 1145-1149.

7. Devereux RB, Savage DD, Sachs I, Laragh JH (1983) Relation of hemodynamic load to left ventricular hypertrophy and performance in hypertension. Am J Cardiol 51: 171-176.

8. Schlaich MP, Kaye DM, Lambert E, Sommerville Mm, Socratous F, et al. (2003) Relation between cardiac sympathetic activity and hypertensive left ventricular hypertrophy. Circulation 108: 560-565

9. Vos MA, de Groot SH, Verduyn SC, van der Zande J, Leunissen HD, et al. (1998) Enhanced susceptibility for acquired torsade de pointes arrhythmias in the dog with chronic, complete AV block is related to cardiac hypertrophy and electrical remodeling. Circulation 98: 1125-1135.

10. Drayer JIM, Weber MA, de Young JL (1983) Blood pressure as a determinant of cardiac left ventricular muscle mass. Arch Intern Med 143: 90-92.

11. Ostman-Smith I (1981) Cardiac sympathetic nerves as the final common pathway in the induction of adaptive cardiac hypertrophy. Clin Sci 61: 265-272.

12. Simpson P (1983) Norepinephrine-stimulated hypertrophy of cultured rat myocardial cells is an alpha-1 adrenergic response. J Clin Invest 72: 732-738.

13. Corea L, Bentivoglio M, Verdecchia P (1983) Echocardiographic left ventricular hypertrophy as related to arterial pressure and plasma norepinephrine concentration in arterial hypertension: reversal by atenolol treatment. Hypertension 5: 837-843

14. Devereux RB, Savage DD, Sachs I, Laragh JH (1980) Effect of blood pressure control on left ventricular hypertrophy and function in hypertension [Abstract]. Circulation 62: 36.

15. Kaul U, Mohan JC, Bhatai ML (1984) Effects of labetalol on left ventricular mass and function in hypertension: an assessment by serial echocardiography Int $\mathrm{J}$ Cardiol 5: 461-469.

16. Weinberg P, Berezow J, Charlap S, Kimmel B, Dorsa F, et al. (1984) Inability of oral labetalol to reverse left-ventricular hypertrophy in hypertensive patients-a non-invasive assessment. Clinical Research 32: A341-A341.

17. Shub C, Cueto-Garcia L, Sheps SG, Ilstrup DM, Tajik AJ (1986) Echocardiographic findings in pheochromocytoma. Am J Cardiol 57: 971- 975.

18. Robertson AL, Khairallah P (1971) Angiotensin II: Rapid localization in nuclei of smooth and cardiac muscle. Science 172: 1138-1139.

19. Khairallah PA, Kanabus $\mathrm{J}$ (1983) Angiotensin and myocardial protein synthesis Cardiac Hypertrophy in Hypertension: 337-347.

20. Dunn FG, Oigman W, Ventura HO, Messerli FH, Kobrin I, et al. Systemic and renal effects of enalapril and its effect on cardiac mass. J Hypertens 2: 57-61.

21. Nakashima Y, Fouad FM, Tarazi RC (1984) Regression of left ventricula hypertrophy from systemic hypertension by enalapril. Am J Cardiol 53: 1044 1049.

22. Devereux RB, Case DB, Cody RJ, Sachs I, Laragh JH (1981) Captopri treatment of hypertension increases low but not normal cardiac index [Abstract] Clin Res 29: 356A.

23. Mary Anne Koda-Kimble, Lloyd Yee Young, Brian K (2009) Alldredge Hypertension, Applied therapeutics. The clinical use of drugs (9th edn), Lippincott Williams \& Wilkins, US. pp: 13-18.

24. Hirning LD, Fox AP, Mc Cleskey EW, Olivera BM, Thayer SA, et al. (1988) Dominant role of $\mathrm{N}$-type $\mathrm{Ca} 2+$ channels in evoked release of norepinephrine from sympathetic neurons. Science 239: 57-61.

25. Zaman ZA, Kumari V (2013) Comparison of the effects of amlodipine and cilnidipine on blood pressure, heart rate, proteinuria and lipid profile in hypertensive patients. Int J Basic Clin Pharmacol 2: 160-164.

26. Tsutamoto T, Tsutsui T, Maeda K, Hayashi M, Wada A, et al. (2003) Effects of long-acting calcium channel antagonists on neurohumoral factors: Comparison of nifedipine coat-core with amlodipine. J Cardiovasc Pharmacol 41: 77-81.

27. Klar J, Sigl M, Obermayer B, Schweda F, Kramer BK, et al. (2005) Calcium inhibits renin gene expression by transcriptional and posttranscriptional mechanisms. Hypertension 46: 1340-1346.
28. Lai EY, Wang Y, Persson AEG, Manning RD, Liu R (2011) Pressure induces intracellular calcium changes in juxtaglomerular cells in perfused afferent arterioles. Hypertens Res 34: 942-948.

29. Takahara A, Dohmoto H, Hisa H, Satoh S, Yoshimoto R (1997) Cilnidipine attenuates renal nerve stimulation-induced renal vasoconstriction and antinatriuresis in anesthetized dogs. Jpn J Pharmacol 75: 27-32.

30. Nagayama T, Yoshida M, Suzukikusaba M, Hisha H, Kimura T, et al. (1998) Effect of cilnidipine, a novel dihydropyridine calcium channel blocker, on adrenal catecholamine secretion in anesthetized dogs. J Cardiovasc Pharmacol 32 479-484.

31. Takahara A (2009) Cilnidipine: A new generation Ca2+ channel blocker with inhibitory action on sympathetic neurotransmitter release. Cardiovasc Ther 27 124-139.

32. Konda T, Enomoto A, Matsushita J, Takahara A, Moriyama T (2005) The Nand L-type calcium channel blocker cilnidipine suppresses renal injury in Dah rats fed a high-sucrose diet, an experimental model of metabolic syndrome. Nephron Physiol 101: 1-13.

33. Klingbeil AU, Schneider M, Martus P, Messerli FH, Schmieder RE (2003) A meta-analysis of the effects of treatment on left ventricular mass in essential hypertension. Am J Med 115: 41-46.

34. Fagard RH, Celis H, Thijs L, Wouters S (2009) Regression of left ventricula mass by antihypertensive treatment a meta-analysis of randomized comparative studies. Hypertension 54: 1084-1091.

35. Himelman RB, Cassidy MM, Landzberg JS, Schiller NB (1988) Reproducibility of quantitative two-dimensional echocardiography. Am Heart J 115: 425-31.

36. Stollberger C, Hollander I, Dimitrov L, Slany J (1996) Influence of measurement inaccuracies on determination of left ventricular mass by $M$ mode echocardiography. Heart 75: 312-313.

37. De Leonardis V, Cinelli $P$ (1986) Evidence of no interobserver variability in M-mode echocardiography. Clin Cardiol 9: 324-326.

38. Collins HW, Kronenberg MW, Byrd BF (1989) Reproducibility of left ventricular mass measurements by two-dimensional and Mmode echocardiography. J Am Coll Cardiol 14: 672-676

39. Fast JH (1989) Limits of reproducibility of left ventricular wall thickness and mass by M-mode echocardiography. Neth J Med 34: 297-301.

40. Lantelme P, Bouchayer D, Gayet C, Lievre M, Gessek J, et al. (1999) Influence of a rapid change of left ventricular dimensions on the echocardiographic measurement of left ventricular mass by the Penn convention. J Hypertens 17:1323-1328.

41. Palmieri V, Dahlof B, DeQuattro V, Sharpe N, Bella JN, et al. (1999) Reliability of echocardiographic assessment of left ventricular structure and function. J Am Coll Cardiol 34: 1625-1632.

42. De Simone G, Muiesan ML, Ganau A, Longhini C, Verdecchia P, et al. (1999) Reliability and limitations of echocardiographic measurement of left ventricular mass for risk stratification and follow-up in single patients. J Hypertens 17 1955-1963.

43. Y Onose, T Oki, H Yamada, K Manabe, Y Kageji, et al. (2001) Effect of cilnidipine on left ventricular diastolic function in hypertensive patients as assessed by pulsed Doppler echocardiography and pulsed tissue Doppler imaging. Jpn Circ J 65: 305-309.

44. Aota Y, Morimoto S, Sakuma T, Morita T, Jo F, et al. (2009) Efficacy of an L- and $\mathrm{N}$-type calcium channel blocker in hypertensive patients with neurovascular compression of the rostral ventrolateral medulla. Hypertension Research 32 : 700-705.

45. Islim IF, Watson RD, Ihenacho HN, Ebanks M, Singh SP (2001) Amlodipine: Effective for treatment of mild to moderate essential hypertension and left ventricular hypertrophy. Cardiology 96: 10-18.

46. Fak AS, Okucu M, Tezcan H, Bodur G, Oktay A (1996) The effects of amlodipine on left ventricular mass and diastolic function in concentric and eccentric left ventricular hypertrophy. J Cardiovasc Pharmacol Ther 1: 95-100.

47. Oliván J, Moreno R, Hoyos M, Ramos E, Rodríguez A, et al. (1996) Effect of the treatment with amlodipine on left ventricular hypertrophy in hypertensive patients. An Med Interna 13: 531-536.

48. Takatsu M, Hattori T, Murase T, Ohtake M (2012) Comparison of the effects of cilnidipine and amlodipine on cardiac remodeling and diastolic dysfunction in 
Citation: Sarkar S, Srivastava V, Mohanty M (2017) Comparison of Efficacy of Amlodipine and Cilnidipine on Left Ventricular Hypertrophy amongst Hypertensive Patients. J Hypertens (Los Angel) 6: 244. doi: 10.4172/2167-1095.1000244

Dahl salt-sensitive rats. J Hypertens 30: 1845-1855.

49. Kanaoka T, Tamura K, Wakui H, Ohsawa M, Azushima K, et al. (2013) $\mathrm{L} / \mathrm{N}$-Type calcium channel blocker cilnidipine added to renin-angiotensin inhibition improves ambulatory blood pressure profile and suppresses cardiac hypertrophy in hypertension with chronic kidney disease. Int J Mol Sci 14: 16866-16881.

50. Takami T, Shigematsu M (2003) Effects of calcium channel antagonists on left ventricular hypertrophy and diastolic function in patients with essential hypertension. Clin Exp Hypertens 25: 525-535.

51. Karlberg BE (1983) Adrenergic regulation of renin release and effects on angiotensin and aldosterone. Acta Med Scand 213: 33-40.

52. Porthan K, Viitasalo M, Hiltunen TP, Vaananen H, Dabek J, et al. (2009) Short-term electrophysiological effects of losartan, bisoprolol, amlodipine, and hydrochlorothiazide in hypertensive men. Ann Med 41: 29-37.

53. Lefrandt JD (2001) The effects of dihydropyridine and phenylalkylamine calcium antagonist classes on autonomic function in hypertension: The VAMPHYRE study. Am J Hypertens 14: 1083-1089.
54. Struck J, Muck P, Trubger D, Handrock R, Weidinger G, et al. (2002) Effects of selective angiotensin II receptor blockade on sympathetic nerve activity in primary hypertensive subjects. J Hypertens 20: 1143-1149.

55. Yoshida C, Goda A, Naito Y, Nakaboh A, Matsumoto M, et al. (2011) Role of plasma aldosterone concentration in regression of left-ventricular mass following antihypertensive medication. J Hypertens 29: 357-363.

56. Zhi-yong Ma, Li L, Xue-zhen Z, Hong-wei T, Rong W, et al. (2007) Cilnidipine Improves left-ventricular midwall function independently of blood pressure changes in chinese patients with hypertension. J Cardiovascular Pharmacology 49: 33-38.

57. Silke B, Verma SP, Zezulka AV, Sharma S, Reynolds G, et al. (1990) Haemodynamic and radionuclide effects of amlodipine in coronary artery disease. Br J Clin Pharmacol 29: 437-445.

58. Feder JM, Metzger JP, Georges JL, Tabone X (1996) Tolerance of amlodipine in left ventricular dysfunction of ischemic origin. Arch Mal Coeur Vaiss 89: 305310.

59. Jan B, Jan KM, Henning K (1999) Amlodipine reduces myocardial ischaemia during exercise without compromising left ventricular function in patients with silent ischaemia: A randomised, double-blind,placebo-controlled study. Eur J Heart Failure 1: 395-400. 